\title{
Soil phosphorus availability and uptake by mycorrhizal and non-mycorrhizal plants in an onion no-tillage system
}

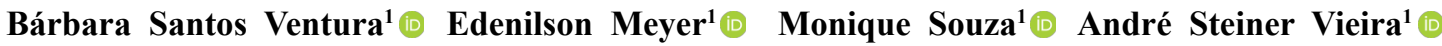

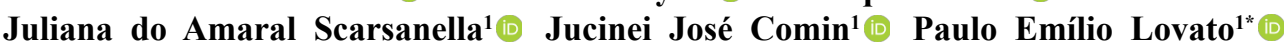

${ }^{1}$ Núcleo de Ensino, Pesquisa e Extensão em Agroecologia, Departamento de Engenharia Rural, Centro de Ciências Agrárias, Universidade Federal de Santa Catarina (UFSC), Florianópolis, SC, Brasil. E-mail: paulo.lovato@ufsc.br. "Corresponding author.

\begin{abstract}
Onion is an important vegetable crop, predominantly grown under conventional tillage system management. Alternatively the vegetable no-tillage system uses cover crops to form a residue layer, which improves soil physical, chemical, and biological attributes. Aiming to understand the interaction of mycorrhizal and non-mycorrhizal cover crops, phosphatase activity, and soil phosphorus availability and uptake by plants, a no-tillage vegetable production system experiment with onion was carried out in Ituporanga, Southern Brazil. The treatments were black oats (Avena strigosa); rye (Secale cereale); oilseed radish (Raphanus sativus); rye + oilseed radish; black oats + oilseed radish, and a control with spontaneous plants. Additionally, two plots, a conventional tillage system area and a forest, both adjacent to the experiment, were evaluated. We measured cover crop biomass, onion yield, acid phosphatase activity, and resin-extracted phosphorus in the soil, shoot and root phosphorus content, and root colonization in cover crops, spontaneous plants, and onions. The treatments with cover crops had the highest plant biomass in winter and onion yield. Available soil phosphorus and acid phosphatase activity were higher in no-tillage plots than in the conventional tillage system area. The presence of non-mycorrhizal oilseed radish was associated with decreased colonization of rye and onion roots by arbuscular mycorrhizal fungi. No-tillage areas with cover crops or spontaneous plants in winter accumulated more phosphorus than conventional tillage system areas. The conventional tillage system showed adverse effects on most soil attributes, as shown by a Principal Component Analysis.
\end{abstract}

Key words: Allium cepa, Acid phosphatase, resin-extracted phosphorus, conventional tillage, cover crops.

Disponibilidade e absorção de fósforo no solo por plantas micorrízicas e não micorrízicas em sistema de plantio direto de cebola

RESUMO: A cebola é uma importante cultura vegetal, cultivada predominantemente sob sistema de preparo convencional. Como alternativa, o sistema de plantio direto de hortaliças utiliza culturas de cobertura para formar uma camada de biomassa, o que melhora os atributos fisicos, químicos e biológicos do solo. Com o objetivo de entender a interação de culturas de cobertura micorrízicas e não-micorrízicas, atividade da fosfatase ácida e disponibilidade e absorção de fósforo do solo pelas plantas, foi realizado um experimento em sistema de plantio direto de hortaliças com a cultura da cebola em Ituporanga, sul do Brasil. Os tratamentos foram: aveia preta (Avena strigosa); centeio (Secale cereale); nabo forrageiro (Raphanus sativus); centeio + nabo forrageiro; aveia preta + nabo forrageiro e um controle com vegetação espontânea. Além disso, duas outras parcelas, uma área em sistema de preparo convencional e uma floresta, ambas adjacentes ao experimento, foram avaliadas. Medimos a biomassa da cultura de cobertura, o rendimento de cebola, a atividade de fosfatase ácida e o fósforo extraído por resina no solo, bem como o conteúdo de fósforo da parte aérea e da raiz e a colonização das raízes em plantas de cobertura, plantas espontâneas e cebolas. Os tratamentos com plantas de cobertura apresentaram a maior biomassa de culturas de cobertura e rendimento de cebola. A atividade de fosfatase ácida e fósforo disponível no solo foram maiores nas parcelas de plantio direto do que na área convencional. A presença de nabo forrageiro, uma planta não micorrizica, foi associada a reduções na colonização de raízes de centeio e cebola por fungos micorrízicos arbusculares. As áreas de plantio direto com plantas de cobertura ou plantas espontâneas no inverno acumularam mais fósforo do que as áreas com preparo convencional. O sistema convencional de lavoura mostrou efeitos adversos para a maioria dos atributos do solo, como mostra a Análise de Componentes Principais.

Palavras-chave: Allium cepa, fosfatase ácida, fósforo extraído por resina, preparo convencional do solo, plantas de cobertura.

\section{INTRODUCTION}

Onions are among the most commonly grown vegetables worldwide. Crop management predominantly uses conventional tillage systems, with intensive use of pesticides and highly soluble fertilizers (FERREIRA et al., 2018). Successive plowing, harrowing, or scarification lead to soil, water, and nutrient losses due to erosion (PANACHUKI et al., 2011; SANTOS et al., 2017; FERREIRA et al., 
2018). Consequently, soils in the producing regions, such as the Upper Itajaí Valley in southern Brazil, are heavily degraded (COMIN et al., 2018a).

As an alternative to the conventional tillage system, our team has been developing a vegetable notillage system for different plant species (FAYAD et al., 2019). It follows ecology-based principles, such as reduced soil tillage, split fertilizer application, and avoidance of highly soluble fertilizers. The system relies on the use of cover crops, aiming to eliminate herbicides for the management of spontaneous plants (FAYAD et al., 2019; MÜLLER JÚNIOR et al., 2019). The vegetable no-tillage system uses cover crops to form a layer of plant residues on the soil surface and minimize tillage. Cover crops can uptake minerals from deeper soil layers, accumulate them in their roots and shoots, thus improving nutrient supply and cycling (OLIVEIRA et al., 2017). After residue decomposition, nutrients in the plant tissues are released and can be uptaken by cash crops (WHITE \& WEIL, 2011). In addition to changes in nutrient concentration in the upper layers, cover crops promote changes in soil structure (SANTOS et al., 2018), reduction of erosion processes (COMIN et al., 2018a), as well as increased soil biological activity and organic matter concentration (DE PONTES et al., 2017). Increased plant diversity should result in higher soil microbiological activity, but studies evaluating soil quality with microbiological indicators are still scarce (MENDES et al., 2019). The selection of biological indicators is vital for the development and scaling up of the vegetable notillage system since they help to understand the underlying biochemical and ecological interactions. Biological indicators can also be used by technicians and farmers to monitor soil quality.

Management practices used in conventional tillage system and vegetable no-tillage system affect soil microbial communities, such as arbuscular mycorrhizal fungi, which have their diversity affected by soil tillage (CARNEIRO et al., 2019). Arbuscular mycorrhizal fungi associated with plant roots provide an increased area for nutrient uptake, especially phosphorus, through their network of hyphae (SMITH \& READ, 2008). Mycorrhizal colonization is affected by soil available phosphorus content, but previous studies on the same area did not show differences in Mehlich 1-extracted soil phosphorus (SOUZA et al., 2013, SANTOS et al., 2017), showing the need to use other extractor, such as resin. Besides, arbuscular mycorrhizal fungi promote soil aggregation, due to the action of their external mycelia and the production of glomalin, a cementing agent (RILLIG \& MUMMEY, 2006). Mycorrhizas have also been linked to increased phosphatases activity in the soil (TAWARAYA et al., 2006).

Enzymes are good indicators of soil quality since they catalyze different reactions in soils (MENDES et al., 2019), involving processes such as organic waste decomposition and nutrient mineralization (BOWLES et al., 2014). Soil enzyme activity is affected by the microbiota, plant cover, and plant and soil management. Arbuscular mycorrhizal fungi can produce enzymes, especially phosphatases, which promote phosphorus mineralization and may act in the solubilization for inorganic phosphate (TARAFDAR, 1995; QIU et al., 2018). Nonmycorrhizal plants have developed strategies to obtain organic phosphorus, which include increased phosphatase activity around their roots (DALLA COSTA \& LOVATO, 2004; KUNZE et al., 2011). However, there is limited information on the relationship between enzyme activity, especially phosphatases, and the presence of mycorrhizal and non-mycorrhizal plants on the tillage system. Our main hypothesis is that plant species, along with soil phosphorus availaibility, can differentially affect phosphatase activity in soils.

This study aims to evaluate the effect of mycorrhizal and non-mycorrhizal cover crops on soil phosphatase activity and phosphorus availability and uptake in a no-tillage onion production system.

\section{MATERIALS AND METHODS}

\section{Location and experimental design}

The study was carried out in Ituporanga (Santa Catarina State, Brazil) (27 24 ' 52 ' $\mathrm{S}, 49^{\circ} 36^{\circ}$ ' 9 "W, $475 \mathrm{~m}$ altitude). The region climate, according to the Köeppen classification, is subtropical humid (Cfa), with a mean temperature of $17.6{ }^{\circ} \mathrm{C}$ and 1400 $\mathrm{mm}$ yearly rainfall. The soil in the area is classified as Cambissolo Húmico (EMBRAPA, 2013), equivalent to Humic Distrudept (SOIL SURVEY STAFF, 2010). The area had a history of twenty years of onion cultivation in conventional tillage system (plowing, harrowing, and scarification) until 1996 when a minimum tillage system with onion and cover crop rotation was adopted. The rotation included oats (Avena strigose Schreb), velvet bean (Mucuna aterrima Piper \& Tracy), millet (Pennisetum glaucum L.), crotalaria (Crotalaria juncea L.), and vetch (Vicia sativa L.). In 2007, sweet potato (Ipomoea patatas (L.) Lam.) was planted and grown until 2009, when the vegetable no-tillage system experiment with onion was established. Spontaneous plants were desiccated 
with glyphosate, and afterward, no pesticide was used in the area. In the $0-10 \mathrm{~cm}$ layer, the soil had $380 \mathrm{~g} \mathrm{~kg}^{-1}$ clay, $40 \mathrm{~g} \mathrm{~kg}^{-1}$ total organic carbon, $6.2 \mathrm{pH}$ in water, $26.6 \mathrm{mg} \mathrm{dm}^{-3}$ available phosphorus, and $145.2 \mathrm{mg}$ $\mathrm{dm}^{-3}$ exchangeable potassium (the latter two extracted by Mehlich-1 solution), $0.0 \mathrm{mmol}_{\mathrm{c}} \mathrm{kg}^{-1}$ exchangeable aluminum, $7.2 \mathrm{cmol}_{\mathrm{c}} \mathrm{kg}^{-1}$ exchangeable calcium, and $3.4 \mathrm{cmol} \mathrm{kg}^{-1}$ exchangeable magnesium (extracted by $1 \mathrm{~mol} \mathrm{~L}^{-1} \mathrm{KCl}$ ) (TEDESCO et al., 1995).

The treatments were: $100 \%$ black oats (Avena strigosa Schreb), with sowing mass of 120 $\mathrm{kg} \mathrm{ha}^{-1} ; 100 \%$ rye (Secale cereale L.), with sowing mass of $120 \mathrm{~kg} \mathrm{ha}^{-1} ; 100 \%$ oilseed radish (Raphanus sativus L.), with $20 \mathrm{~kg} \mathrm{ha}^{-1}$; intercropping of rye $(86 \%)$ and oilseed radish (14\%), with 60 and 10 $\mathrm{kg} \mathrm{ha} \mathrm{h}^{-1}$, respectively; intercropping of black oats $(86 \%)$ and oilseed radish $(14 \%)$, with 60 and 10 $\mathrm{kg} \mathrm{ha} \mathrm{h}^{-1}$, respectively. The sixth treatment was a fallow control with spontaneous plants, with the predominance of Amaranthus lividus L., Oxalis spp., Cyperus spp., Stachys arvensis L. Cynodon spp., and Rumex obtusifolius L. (SOUZA et al., 2018). Seed densities for cover crops were defined based on the recommendation of MONEGAT (1991) and increased by $50 \%$, aiming a suitable dry mass production for the system, around $5.0 \mathrm{Mg} \mathrm{ha}^{-1}$. The cover crops are winter species and were sown in early Autumn (April) each year.

In July of every year (2009 to 2017), all winter cover crops were rolled down with a knife roller (model RF240, MBO Ltda., Erechim, Brazil). We used fertilizer doses and applicartion procedures usually adopted by onion farmers in the region: Gafsa natural phosphate at a rate of $96 \mathrm{~kg} \mathrm{P}_{2} \mathrm{O}_{5} \mathrm{ha}^{-1}$, and poultry litter, corresponding to $175 \mathrm{~kg} \mathrm{ha}^{-1}$ of $\mathrm{P}_{2} \mathrm{O}_{5}$, $125 \mathrm{~kg} \mathrm{ha}^{-1}$ of $\mathrm{K}_{2} \mathrm{O}$ and $160 \mathrm{~kg} \mathrm{ha}^{-1}$ of $\mathrm{N}$. One half of the poultry litter was applied at onion seedling planting, and the remainder was applied 45 days later. In 2011, no natural phosphate was applied, as soil analysis showed that levels were very high (CQFSRS / SC, 2004). Furrows were dug with a sowing planter adapted for direct onion planting, and onion seedlings (cultivar Empasc 352 - Bola Precoce) were manually transplanted. Each experimental unit had $25 \mathrm{~m}^{2}(5.0 \times 5.0 \mathrm{~m})$, with $0.40 \mathrm{~m}$ between rows and $0.10 \mathrm{~m}$ between plants, with ten onion rows per plot. Weeding was done by hoeing, 60 and 90 days after the onion seedlings were transplanted. After the onion harvest, in November or December of each year, velvet bean (Mucuna aterrima Piper \& Tracy) was sown $\left(120 \mathrm{~kg} \mathrm{ha}^{-1}\right)$ on the cultivated area. The velvet bean plants were rolled down each April, before sowing the cover crops. The experiment was arranged in a randomized block design with eight replicates. The soil apparent density in the area ranges between 1.28 and $1.32 \mathrm{Mg} \mathrm{m}^{-3}$ (LOSS et al., 2017).

Additionally, two more plots were evaluated, both adjacent to the experiment. The conventional tillage system plot is a 41-year-old onion field. Onions were grown under conventional tillage system for 31 years from 1976 until 2007. Since 2007, onion has been grown in rotation with millet in the summer. Millet was rolled down at flowering with a knife roller, and after 30-60 days, the area was plowed and harrowed to establish the onion crop. The soil (0-10 $\mathrm{cm}$ layer) had $420 \mathrm{~g} \mathrm{~kg}^{-1}$ clay, $5.8 \mathrm{pH}$ in water, $17.1 \mathrm{mg} \mathrm{dm}^{-3}$ available phosphorus, and $80.0 \mathrm{mg} \mathrm{dm}^{-3}$ exchangeable potassium (the latter two extracted by Mehlich-1 solution), 0.0 mmol $_{\mathrm{c}} \mathrm{kg}^{-1}$ exchangeable aluminum, $7.3 \mathrm{cmol}_{\mathrm{c}} \mathrm{kg}^{-1}$ exchangeable calcium, and $3.0 \mathrm{cmol}_{\mathrm{c}} \mathrm{kg}^{-1}$ exchangeable magnesium (extracted by $1 \mathrm{~mol} \mathrm{~L}^{-1} \mathrm{KCl}$ ). Soil apparent density is $1.40 \mathrm{Mg} \mathrm{m}^{-3}$ (LOSS et al., 2017). Fertilizer was applied according to regional recommendations (CQFS-RS / SC, 2004). Also, soil samples were taken in a secondary forest used as a reference to represent an environment without management stress. That area, at a 550-meter distance from the experimental area, has 35 years of regeneration, and soil apparent density is $0.98 \mathrm{Mg} \mathrm{m}^{-3}$ (LOSS et al., 2017).

Sampling and measurements for area characterization The Ituporanga EPAGRI weather station, maintained by the Centro de Informações de Recursos Ambientais e de Hidrometeorologia de Santa Catarina (CIRAM), provided the information on weather conditions (temperature and rainfall daily value) in the period during which the experiment was carried out.

In June and July 2017, at 58, 80, and 99 days after sowing of winter cover crops, three subsamples were collected from each plot, using a $0.5 \mathrm{~m} \times 0.5 \mathrm{~m}$ frame. The plants were cut, stored in paper bags, oven-dried at $65^{\circ} \mathrm{C}$ until constant mass, and weighed.

In November, onion bulbs were harvested manually in six central lines of each plot. left on the soil surface for ten days, sorted by size class (HORTIBRASIL, 2010), and weighed.

Soil phosphatase activity and phosphorus availability Acid phosphatase activity and resinextracted phosphorus were measured in soil samples from all treatments during the cover crop cycle at 58 , 80 and 99 days after sowing, and at 40 and 99 days after seedling planting during the onion cycle. In each plot 
of the experiment and adjacent areas, approximately 300 grams of soil were collected at a depth of 0 to 10 $\mathrm{cm}$. The samples were transported to the laboratory with ice and kept at $4{ }^{\circ} \mathrm{C}$ until the analyses were performed within two months after collecting.

For acid phosphatase activity analysis, 1.0 gram of soil was mixed with p-nitrophenyl phosphate (PNP) in a modified universal buffer (MUB pH 6.5), incubated at $37^{\circ} \mathrm{C}$, and hydrolysis was stopped after one hour with $0.5 \mathrm{~mol} \mathrm{~L}^{-1}$ calcium chloride. $\left(\mathrm{CaCl}_{2}\right)$ and $0.5 \mathrm{~mol} \mathrm{~L}-1 \mathrm{NaOH}$. Absorbance $(410 \mathrm{~nm})$ of the centrifuged and filtered extract was measured in a UV-visible spectrophotometer. Controls were performed using the same procedures with the enzyme substrate ( $p$-nitrophenyl phosphate) added at the end of the incubation period. The standard curve was obtained with p-nitrophenol in $\mathrm{CaCl}_{2}$ and $\mathrm{NaOH}$ (TABATABAI, 1994).

Soil resin-extracted phosphorus was measured using Anion Exchange Resins (RAIJ et al., 1987) after stirring for 16 hours. Subsequently, the resins were removed from the solution, and the phosphate ions were extracted with a $0.5 \mathrm{~mol} \mathrm{~L}^{-1}$ HCL solution. Phosphorus was quantified by UV-vis spectrometry (MURPHY \& RILEY, 1962).

\section{Mycorrhizal root colonization, and shoot phosphorus concentration and uptake}

Root colonization by arbuscular mycorrhizal fungi was measured in rye, oilseed radish, rye + oilseed radish, and spontaneous plants treatments at 80 days after sowing during the winter cover crop cycle, and at 40 and 99 days after seedling planting during the onion cycle. We decided to evaluate only rye because the behavior of grasses is similar, and previous studies in the same experiment showed that rye had better results in soil quality improvement (OLIVEIRA et al., 2016). In the first sampling, three rye and three oilseed radish plants were collected from the single-crop plots and the intercropped rye and oilseed radish plots. In each spontaneous plants plot, three Rumex obtusifolius plants and three Amaranthus lividus plants were collected because those species were present in all treatments. $R$. obtusifolius has a dominance index of 20 to $33 \%$ during winter and onion cycles, respectively, and A. lividus indexes are 17 to $61 \%$ in the same cycles (COMIN et al., 2018b). In the other two sampling times, during the onion cycle, three onion plants were collected in each plot. Onion plants were also collected in the adjacent area with conventional tillage system.

Shoots of three plants of each treatment were oven-dried at $65^{\circ} \mathrm{C}$ until constant mass, weighted, and ground to determine phosphorus concentration and total uptake. Plant material was subjected to digestion in $\mathrm{H}_{2} \mathrm{SO}_{4}$ and $\mathrm{H}_{2} \mathrm{O}_{2}$ (TEDESCO et al., 1995), and phosphorus was determined by spectrometry (MURPHY \& RILEY. 1962).

Roots were transported in ice coolers and stored at $4{ }^{\circ} \mathrm{C}$ for further analysis. Root samples were cleared with $\mathrm{KOH}$ and stained with trypan blue (KOSKE \& GEMMA, 1989), and colonization was measured according to MCGONIGLE et al. (1990). Stained root fragments of $1.0 \mathrm{~cm}$ were mounted on slides with polyvinyl lactoglycerol and examined under a microscope at 200x magnification, and 100 intersections were examined, counting the presence of hyphae, arbuscles, and vesicles.

\section{Statistical analysis}

Data on biomass, yield, mycorrhizal colonization, and phosphorus availability in soil and plants were tested for homogeneity (Bartlett) and normality (Shapiro-Wilk). Mycorrhizal colonization data (hyphae only, arbuscles, vesicles, and total colonization) were transformed using $(\mathrm{x}+1)^{0.5}$. Data were subjected to analysis of variance, and when there were significant effects, means were separated by the Skott Knott test at 5\% probability.

Analyses of regression were performed, followed by analyses of variance at $5 \%$ probability. A principal component analysis was performed using the vegan package (OKSANEN et al., 2013). The software R v. 3.6 (R Development Core Team, 2008) for statistical analysis and the Sigma Plot 12.3 (Systat Corp.) software for graphs were used.

\section{RESULTS}

\section{Winter cover crop biomass and onion yield}

Winter cover crop produced more aboveground biomass than spontaneous plants, in all sampling times (Table 1). At 58 and 99 days after sowing, shoot biomass of intercropped or singlespecies winter cover crops was three times higher than plant biomass in plots with spontaneous plants. In the adjacent area under conventional tillage system, millet biomass production in summer was double the biomass of winter cover crops.

The total yield of onion bulbs ranged from 6.9 $\mathrm{Mg} \mathrm{ha}^{-1}$ for spontaneous plants to $13.9 \mathrm{Mg} \mathrm{ha}^{-1}$ for black oats (Table 1). The treatments previously sown with black oats and black oats + oilseed radish had higher onion yields than the other treatments. In general, onion yields in treatments with cover crops were 32 to $50 \%$ higher than in the plots with 
Table 1 - Winter cover crops biomass in three sampling times, and onion bulb yield in a no-tillage system with black oats (BO), rye (RY), oilseed radish (OR), as single or combined cover crops or with spontaneous plants (SP), with an adjacent conventional tillage system (CTS) having millet as summer cover crop takin as reference. DAS = days after sowing.

\begin{tabular}{|c|c|c|c|c|}
\hline \multirow[t]{2}{*}{ Treatments } & \multicolumn{3}{|c|}{ - } & \multirow[t]{2}{*}{ Onions bulb yield } \\
\hline & $58 \mathrm{DAS}$ & $80 \mathrm{DAS}$ & 99 DAS & \\
\hline & ------------------------ & -----------1 & 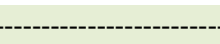 & ------------------------ \\
\hline Black oats (BO) & $1.5 \mathrm{a}^{*}$ & $3.1 \mathrm{a}$ & $4.5 \mathrm{a}$ & $13.9 \mathrm{a}$ \\
\hline Rye (RY) & $1.4 \mathrm{a}$ & $3.2 \mathrm{a}$ & $4.3 \mathrm{a}$ & $10.3 \mathrm{~b}$ \\
\hline Oilseed radish (OR) & $1.5 \mathrm{a}$ & $3.8 \mathrm{a}$ & $4.1 \mathrm{a}$ & $10.2 \mathrm{~b}$ \\
\hline $\mathrm{RY}+\mathrm{OR}$ & $1.7 \mathrm{a}$ & $3.4 \mathrm{a}$ & $4.6 \mathrm{a}$ & $10.2 \mathrm{~b}$ \\
\hline $\mathrm{BO}+\mathrm{OR}$ & $1.6 \mathrm{a}$ & $3.8 \mathrm{a}$ & $4.5 \mathrm{a}$ & $12.6 \mathrm{a}$ \\
\hline Spontaneous Plants & $0.4 \mathrm{~b}$ & $1.7 \mathrm{~b}$ & $1.5 \mathrm{~b}$ & $6.9 \mathrm{c}$ \\
\hline CTS & & & 9.0 & 25.0 \\
\hline
\end{tabular}

${ }^{*}$ Means followed by the same lowercase letter in each column do not differ according to Scott-Knott test $(\mathrm{P} \leq 0.05)$.

spontaneous plants (Table 1), which also had smaller bulbs (Table 2). Bulb yield in conventional tillage system was 1.7 to 3.6 times higher than in vegetable no-tillage system treatments. There was a significant regression coefficient $\left(\mathrm{r}^{2}=0.83 ; p\right.$-value $\left.\left.<0.001\right)\right)$ between cover crop biomass and onion yield.

\section{Mycorrhizal colonization and shoot phosphorus concentration and uptake}

During the winter cover cycle, there was mycorrhizal colonization in the roots of rye (Figure 1), a mycorrhizal plant. No mycorrhizal structures were found in oilseed radish, $R$. obtusifolius, or A. lividus roots, as expected since those plant species belong to typically non-mycorrhizal families (BRUNDRETT, 2017). Total root colonization in treatments containing only rye and intercropped rye species were $20 \%$ and
$12 \%$, respectively, but vesicle and arbuscule indexes did not differ between treatments.

Onion roots were colonized by arbuscular mycorrhizal fungi in both sampling times (Table 3). There were differences among treatments only for total colonization in the first sampling, and for vesicles in the second sampling. In the first sampling time, total root colonization in the treatments with oilseed radish was lower than in the treatments with rye only, with spontaneous plants, or under conventional tillage system. In the second sampling, the highest rate of vesicle formation occurred in the spontaneous plant treatment.

During the cover crop cycle, shoot phosphorus concentration in cover crops and spontaneous plants varied from 4.3 to $5.7 \mathrm{~g} \mathrm{~kg}^{-1}$, at 99 days after sowing (Table 4$)$. Those concentrations

Table 2 - Yield of onion bulbs, separated by commercial class, in a no-tillage onion production system.

\begin{tabular}{|c|c|c|c|c|c|}
\hline \multirow[t]{2}{*}{ Treataments } & \multicolumn{5}{|c|}{ 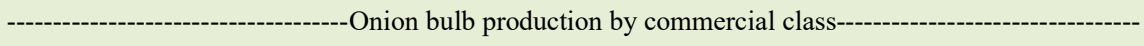 } \\
\hline & Class 1 & Class 2 & Class 3 & Rotten & Total \\
\hline & \multicolumn{5}{|c|}{ 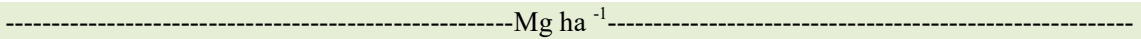 } \\
\hline Black oats (BO) & $0.4 \mathrm{~b}$ & $10.3 \mathrm{a}$ & $2.9 \mathrm{a}$ & $0.1^{\mathrm{ns}}$ & $13.9 \mathrm{a}$ \\
\hline Rye (RY) & $0.4 \mathrm{~b}$ & $7.1 \mathrm{~b}$ & $2.1 \mathrm{a}$ & $0.1^{\mathrm{ns}}$ & $10.3 \mathrm{~b}$ \\
\hline Oilseed radish (OR) & $0.4 \mathrm{~b}$ & $7.0 \mathrm{~b}$ & $2.4 \mathrm{a}$ & $0.1^{\mathrm{ns}}$ & $10.2 \mathrm{~b}$ \\
\hline $\mathrm{RY}+\mathrm{OR}$ & $0.4 \mathrm{~b}$ & $7.8 \mathrm{~b}$ & $2.1 \mathrm{a}$ & $0.2^{\mathrm{ns}}$ & $10.2 \mathrm{~b}$ \\
\hline $\mathrm{BO}+\mathrm{OR}$ & $0.5 \mathrm{~b}$ & $9.2 \mathrm{a}$ & $2.7 \mathrm{a}$ & $0.3^{\mathrm{ns}}$ & $12.6 \mathrm{a}$ \\
\hline Spontaneous Plants & $1.6 \mathrm{a}$ & $4.9 \mathrm{c}$ & $0.3 \mathrm{~b}$ & $0.3^{\mathrm{ns}}$ & $6.9 \mathrm{c}$ \\
\hline
\end{tabular}

* Means followed by the same letter in each column do not differ according to Scott-Knott test $(\mathrm{P}<0.05)$. ns $=$ not significant by the $\mathrm{F}$ test $(\mathrm{p}<0.05)$. Class $1(>15 \leq 35 \mathrm{~mm})$, Class $2(>35 \leq 50 \mathrm{~mm})$, Class $3(>50 \leq 60 \mathrm{~mm})$. 


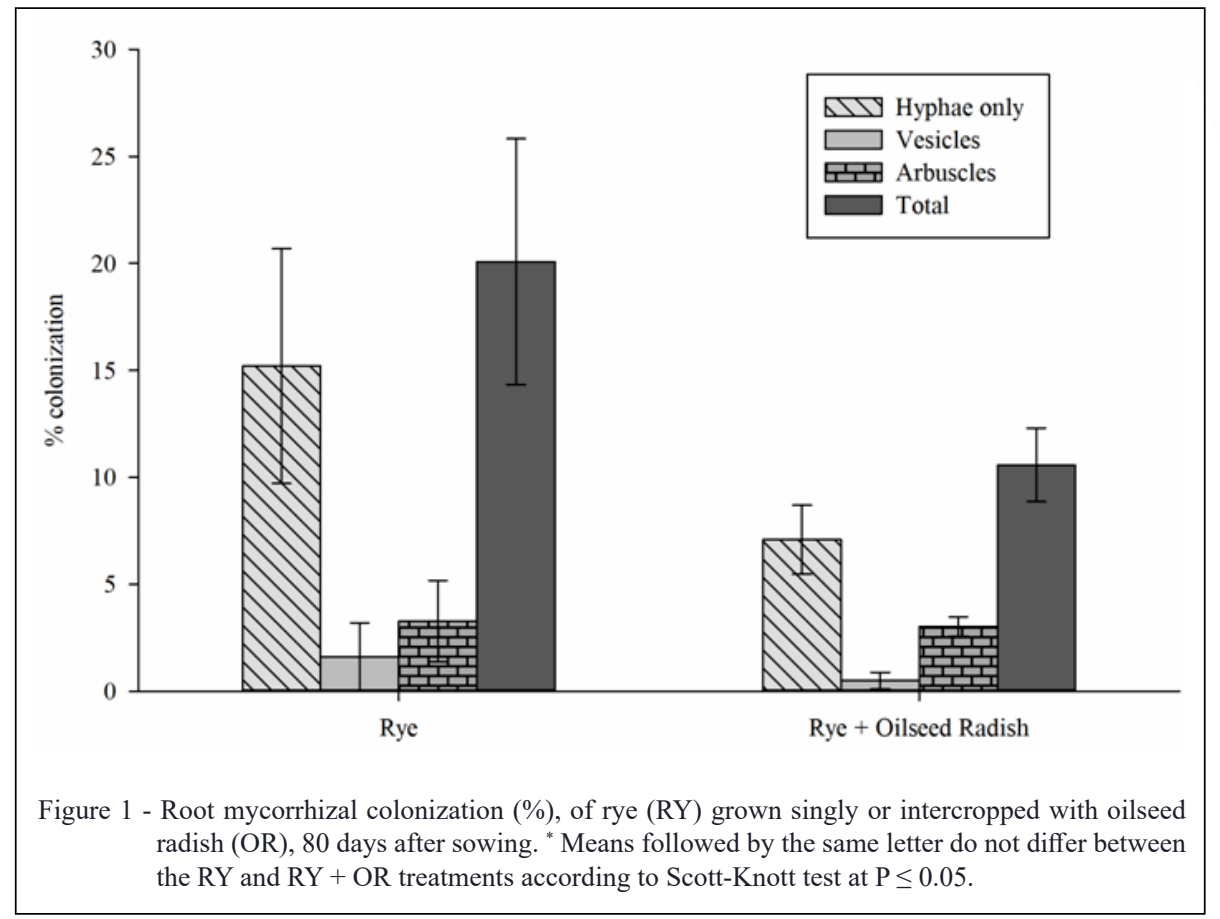

are probably linked to the availability of phosphorus from rock phosphate $\left(96 \mathrm{~kg} \mathrm{P}_{2} \mathrm{O}_{5} \mathrm{ha}^{-1}\right)$ and poultry litter $\left(175 \mathrm{~kg} \mathrm{P}_{2} \mathrm{O}_{5} \mathrm{ha}^{-1}\right)$. Rye and spontaneous plants had the highest shoot phosphorus concentration, while phosphorus uptake was greater in cover crops than in spontaneous plants, mainly due to the difference in biomass production (Table 1). During the onion crop cycle, shoot phosphorus concentration did not differ among treatments, while the highest phosphorus uptake occurred in conventional tillage system plants, and oilseed radish and rye + oilseed radish treatments had the lowest phosphorus uptake rates.

Soil acid phosphatase activity and resin-extracted phosphorus

During the cover crop cycle, acid phosphatase activity ranged from 434 to $1031 \mathrm{ug}$ PNP $g$ dry soil ${ }^{-1} \mathrm{~h}^{-1}$ in the plots in vegetable no-tillage system and in the adjacent production area under conventional tillage system, while it ranged from 1085 to 2297 ug PNP g dry soil ${ }^{-1} \mathrm{~h}^{-1}$ in the forest area,

Table 3 - Mycorrhizal colonization of onion in summer, with onion under conventional tillage system (CTS) taken as references. Hy: hyphae only; Ves: vesicles; Arb: arbuscules. DAS: days after cover crop sowing; DAP: days after onion planting.

\begin{tabular}{|c|c|c|c|c|c|c|c|c|}
\hline Treatments & Hy & Ves & Arb & Total & Hy & Ves & Arb & Total \\
\hline & \multicolumn{4}{|c|}{ 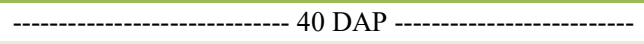 } & \multicolumn{4}{|c|}{------------------------- 99 DAP ------------------------ } \\
\hline Rye (RY) & $6.3^{\mathrm{ns}}$ & $7.3^{\mathrm{ns}}$ & $26.8^{\text {ns }}$ & $39.3 \mathrm{a}$ & $9.5^{\mathrm{ns}}$ & $2.0 \mathrm{~b}$ & $24.0^{\mathrm{ns}}$ & $33.8^{\text {ns }}$ \\
\hline Oilseed radish (OR) & 5.0 & 4.8 & 22.0 & $25.8 \mathrm{~b}$ & 7.8 & $4.8 \mathrm{~b}$ & 21.8 & 25.8 \\
\hline $\mathrm{RY}+\mathrm{OR}$ & 7.0 & 2.8 & 23.5 & $27.8 \mathrm{~b}$ & 7.0 & $2.0 \mathrm{~b}$ & 22.0 & 29.8 \\
\hline Spontaneous plants & 7.3 & 6.8 & 34.3 & $43.3 \mathrm{a}$ & 11.0 & $10.0 \mathrm{a}$ & 17.3 & 30.8 \\
\hline $\mathrm{CV} \%$ & 24.1 & 43.3 & 19.6 & 10.5 & 16.6 & 27.7 & 11.7 & 7.6 \\
\hline CTS $($ mean \pm CI) & $7.8 \pm 4.0$ & $9.0 \pm 5.7$ & $37.3 \pm 11.9$ & $46.0 \pm 13.2$ & $7.8 \pm 5.3$ & $3.3 \pm 1.5$ & $20.8 \pm 7.3$ & $30.3 \pm 5.7$ \\
\hline
\end{tabular}

*Means followed by the same lowercase letter in each column do not differ according to Scott-Knott test at P $<0.05$. ns $=$ not significant; $\mathrm{DAP}=$ Days after onion planting; $\mathrm{CV}=$ coefficient of variation. $\mathrm{CI}=$ confidence interval. 
Table 4 - Phosphorus concentration (PC) $\left(\mathrm{g} \mathrm{kg}^{-1}\right)$ and total uptake (PU) ( $\left.\mathrm{kg} \mathrm{ha}^{-1}\right)$ in cover crops and spontaneous plants (SP), 99 days after sowing, and in onion plants, 99 days after planting. CTS: Conventional tillage system.

\begin{tabular}{|c|c|c|c|c|}
\hline \multirow[t]{2}{*}{ Treatments } & \multicolumn{2}{|c|}{-------------------Cover crops cycle------------------ } & \multicolumn{2}{|c|}{---------------------Onion cycle----------------- } \\
\hline & $\mathrm{PC}\left(\mathrm{g} \mathrm{kg}^{-1}\right)$ & PU $\left(\mathrm{kg} \mathrm{ha}^{-1}\right)$ & $\mathrm{PC}\left(\mathrm{g} \mathrm{kg}^{-1}\right)$ & $\mathrm{PU}\left(\mathrm{kg} \mathrm{ha}^{-1}\right)$ \\
\hline Rye (RY) & $5.7 \mathrm{a}^{*}$ & $23.2 \mathrm{a}$ & $3.4^{\mathrm{ns}}$ & $9.1 \mathrm{a}$ \\
\hline Oilseed radish (OR) & $4.3 \mathrm{~b}$ & $17.6 \mathrm{a}$ & 3.3 & $6.8 \mathrm{~b}$ \\
\hline $\mathrm{RY}+\mathrm{OR}$ & $4.9 \mathrm{~b}$ & $22.5 \mathrm{a}$ & 3.5 & $6.3 \mathrm{~b}$ \\
\hline Spontaneous plants & $5.4 \mathrm{a}$ & $8.1 \mathrm{~b}$ & 3.1 & $9.0 \mathrm{a}$ \\
\hline $\mathrm{CV} \%$ & nd & nd & 18.6 & 20.0 \\
\hline CTS $($ mean \pm CI $)$ & nd & nd & $3.5 \pm 0.3$ & $15.2 \pm 1.8$ \\
\hline
\end{tabular}

${ }^{*}$ Means followed by the same lowercase letter do not differ from each other in the column according to Scott-Knott test $(\mathrm{P} \leq 0.05)$, ns $=$ not significant, $\mathrm{nd}=$ not determined.

used as a reference (Table 5). There was an increase in enzyme activity throughout the three sampling times in all treatments. Acid phosphatase activity in all samplings times during the winter cover crop cycle was higher in black oats and black oats + oilseed radish treatments than in spontaneous plants. In the treatments with single oilseed radish or rye + oilseed radish, acid phosphatase activity only differed from the spontaneous plants in the last sampling time, at 99 days.

During the onion cycle, acid phosphatase activity ranged from 638 to 1230 ug PNP g dry soil ${ }^{1} \mathrm{~h}^{-1}$ in the areas with vegetable no-tillage system and conventional tillage system (Table 5). In both onion cycle samplings, there were no differences among treatments in vegetable no-tillage system, and all values were higher than those found in the area in conventional tillage system. In the forest area, acid phosphatase activity remained higher than in cultivated areas, ranging from 1623 to 1712 ug PNP g dry soil ${ }^{-1} h^{-1}$.

During the cover crop cycle, resinextracted soil phosphorus (Table 6) ranged from 9.7 to $147 \mathrm{mg} \mathrm{kg}^{-1}$ in the vegetable no-tillage system and conventional tillage system areas, and from 11.9 at $14.5 \mathrm{mg} \mathrm{kg}^{-1}$ in the forest area. In the three sampling times, there were no differences in soil phosphorus among cover crops, except for oilseed radish and rye

Table 5 - Acid phosphatase (AP) activity (ug PNP g dry soil ${ }^{-1} \mathrm{~h}^{-1}$ ) in soil under winter cover crop cycle and during summer onion cultivation, in areas with cover crops and subsequent onion cycle, area with onion under conventional tillage system (CTS) and in a forest taken as reference.

\begin{tabular}{|c|c|c|c|c|c|}
\hline \multirow[t]{2}{*}{ Treatments } & \multicolumn{3}{|c|}{-------------AP activity during cover crop cycle------------ } & \multicolumn{2}{|c|}{----AP activity during onion cycle--- } \\
\hline & $58 \mathrm{DAS}$ & $80 \mathrm{DAS}$ & 99 DAS & 40 DAP & 99 DAP \\
\hline Black oats $(\mathrm{BO})$ & $757 \mathrm{aB}^{*}$ & $990 \mathrm{aA}$ & $1031 \mathrm{aA}$ & $994 a^{\text {ns }}$ & $1230 \mathrm{a}$ \\
\hline Rye (RY) & $770 \mathrm{aB}$ & $928 \mathrm{bA}$ & $987 \mathrm{aA}$ & $969 \mathrm{a}$ & $1187 \mathrm{a}$ \\
\hline Oilseed radish (OR) & $689 \mathrm{bB}$ & $884 \mathrm{bA}$ & $936 \mathrm{aA}$ & $953 \mathrm{a}$ & 1213 a \\
\hline $\mathrm{RY}+\mathrm{OR}$ & $642 \mathrm{bB}$ & $905 \mathrm{bA}$ & $958 \mathrm{aA}$ & $1021 \mathrm{a}$ & $1171 \mathrm{a}$ \\
\hline $\mathrm{BO}+\mathrm{OR}$ & $849 \mathrm{aB}$ & $983 \mathrm{aA}$ & $987 \mathrm{aA}$ & $997 \mathrm{a}$ & $1182 \mathrm{a}$ \\
\hline Spontaneous Plants & $719 \mathrm{bB}$ & $851 \mathrm{bA}$ & $848 \mathrm{bA}$ & $926 \mathrm{a}$ & $1053 \mathrm{a}$ \\
\hline $\mathrm{CV} \%$ & 14.0 & 10.7 & 15.8 & 13.0 & 17.4 \\
\hline CTS (mean \pm CI) & $434 \pm 48$ & $690 \pm 62$ & $670 \pm 76$ & $638 \pm 103$ & $680 \pm 110$ \\
\hline Forest (mean $\pm \mathrm{CI})$ & $1085 \pm 315$ & $2140 \pm 203$ & $2297 \pm 792$ & $1623 \pm 377$ & $1712 \pm 386$ \\
\hline
\end{tabular}

*Means followed by the same letter, lowercase in each column and uppercase in each row, do not differ according to Scott-Knott test (P $<0.05) . \mathrm{ns}=$ not significant for analysis between collections during onion cycle; DAS = Days after sowing; DAP = Days after seedling planting; $\mathrm{CV}=$ coefficient of variation. $\mathrm{CI}=$ confidence interval. 
Table 6 - Resin-extracted soil phosphorus $\left(\mathrm{mg} \mathrm{kg}^{-1}\right)$ in the soil during the winter cover crop cycle and summer onion cultivation, in plots with cover crops and subsequent onion cycle, in areas with onion under conventional tillage system (CTS), and a forest taken as reference.

\begin{tabular}{|c|c|c|c|c|c|}
\hline \multirow[t]{2}{*}{ Treatments } & \multicolumn{3}{|c|}{ 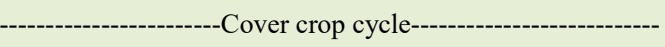 } & \multicolumn{2}{|c|}{-----------Onion cycle--------- } \\
\hline & 58 DAS & 80 DAS & 99 DAS & 40 DAP & 99 DAP \\
\hline & \multicolumn{5}{|c|}{ 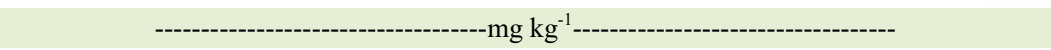 } \\
\hline Black oats (BO) & $145 \mathrm{aA}^{*}$ & $110 \mathrm{aB}$ & $104 \mathrm{aB}$ & $144 \mathrm{a}$ & $162 \mathrm{a}$ \\
\hline Rye (RY) & $147 \mathrm{aA}$ & $111 \mathrm{aB}$ & $95 \mathrm{aB}$ & $145 \mathrm{a}$ & $166 \mathrm{a}$ \\
\hline Oilseed radish $(\mathrm{OR})$ & $123 \mathrm{bA}$ & $119 \mathrm{aA}$ & $116 \mathrm{aA}$ & $139 \mathrm{a}$ & $155 \mathrm{a}$ \\
\hline $\mathrm{RY}+\mathrm{OR}$ & $107 \mathrm{bB}$ & $127 \mathrm{aA}$ & $91 \mathrm{aB}$ & $137 \mathrm{a}$ & $184 \mathrm{a}$ \\
\hline $\mathrm{BO}+\mathrm{OR}$ & $141 \mathrm{aA}$ & $132 \mathrm{aA}$ & $95 \mathrm{aB}$ & $178 \mathrm{a}$ & $173 \mathrm{a}$ \\
\hline Spontaneous Plants & $135 \mathrm{aA}$ & $125 \mathrm{aA}$ & $108 \mathrm{aA}$ & $174 \mathrm{a}$ & $173 \mathrm{a}$ \\
\hline $\mathrm{CV} \%$ & 17.07 & 23.8 & 13.3 & 18.8 & 27.5 \\
\hline $\mathrm{CTS}(\operatorname{mean} \pm \mathrm{CI})$ & $9.7 \pm 5.2$ & $51 \pm 8.9$ & $53 \pm 10.8$ & $57 \pm 7.2$ & $64 \pm 15.7$ \\
\hline Forest (mean $\pm \mathrm{CI})$ & $12.9 \pm 1.2$ & $11.9 \pm 2.0$ & $14.5 \pm 2.1$ & $14.2 \pm 2.0$ & $15.4 \pm 1.4$ \\
\hline
\end{tabular}

*Means followed by the same letter, lowercase in each column, and uppercase in each row, do not differ according to Scott-Knott test (P $<0.05)$. DAS = Days after sowing; DAP $=$ Days after seedling planting; $\mathrm{CV}=$ coefficient of variation. $\mathrm{CI}=$ confidence interval.

+ oilseed radish treatments at 58 days after sowing, which had higher resin-extracted phosphorus than conventional tillage system and forest. In general, there was a decrease in soil phosphorus throughout the three sampling times in all treatments in the vegetable no-tillage system, except for oilseed radish and spontaneous plants (Table 4). During the onion cycle, resin-extracted phosphorus ranged from 57 to $184 \mathrm{mg} \mathrm{kg}^{-1}$ in the areas under vegetable no-tillage system and conventional tillage system, and from 14.2 to $15.4 \mathrm{mg} \mathrm{kg}^{-1}$ in the forest area. In the onion cycle samplings, resin-extracted phosphorus did not differ among vegetable no-tillage system treatments, which had higher values than the conventional tillage system and forest area.

\section{Interactions among variables}

The correlations between the variables resin-extracted phosphorus and acid phosphatase activity (Figure 2) show two different behaviors. During the winter cover crop cycle $(58,80$, and 99 days after sowing), correlations are moderate and positive, while in the onion cycle (40 and 99 days after seedling planting), correlations are strong and negative.

The principal component analysis explained $75.4 \%$ of the data variance in the two main components. PC1 explained $57.9 \%$ of the variance and grouped the highest values of the attributes related to phosphorus availability (phosphorus concentration, acid phosphatase, resin-extracted phosphorus, and phosphorus uptake) with no-till treatments (Figure
3). The conventional production system correlated with the lowest values in soil attributes related to phosphorus availability and cycling. PC2 explained $17.5 \%$ of the variance and separated phosphorus availability attributes and onion colonization at 99 days after onion seedling planting.

\section{DISCUSSION}

\section{Winter cover crop biomass and onion yield}

Lower biomass production in the fallow control area (spontaneous plants) than in areas with cover crops is due to lower biomass production and slower growth by the spontaneous plants (HERTWIG BITTENCOURT et al., 2013), resulting in low availability of nutrients derived from plant residue decomposition (PISSINATI, MOREIRA, \& SANTORO, 2016). When plant cover is scarce, the soil is also more exposed to rainfall, increasing the probability of particle and nutrient losses by erosion and runoff (PANACHUKI et al., 2011). That seems to have affected the onion yield, which had the lowest total bulb yield in the area without the use of cover crops. Onion yield was affected by a drought of approximately 40 days, which was associated with a mean temperature of $19.4{ }^{\circ} \mathrm{C}$ in September (Figure 4), which is above the September average, that ranges between 15 and $16^{\circ} \mathrm{C}$ (https://ciram.epagri.sc.gov.br/ index.php/solucoes/climatologia/). The high thermal amplitude in this period, at the stage of bulb formation may also have resulted in smaller bulbs. In previous 


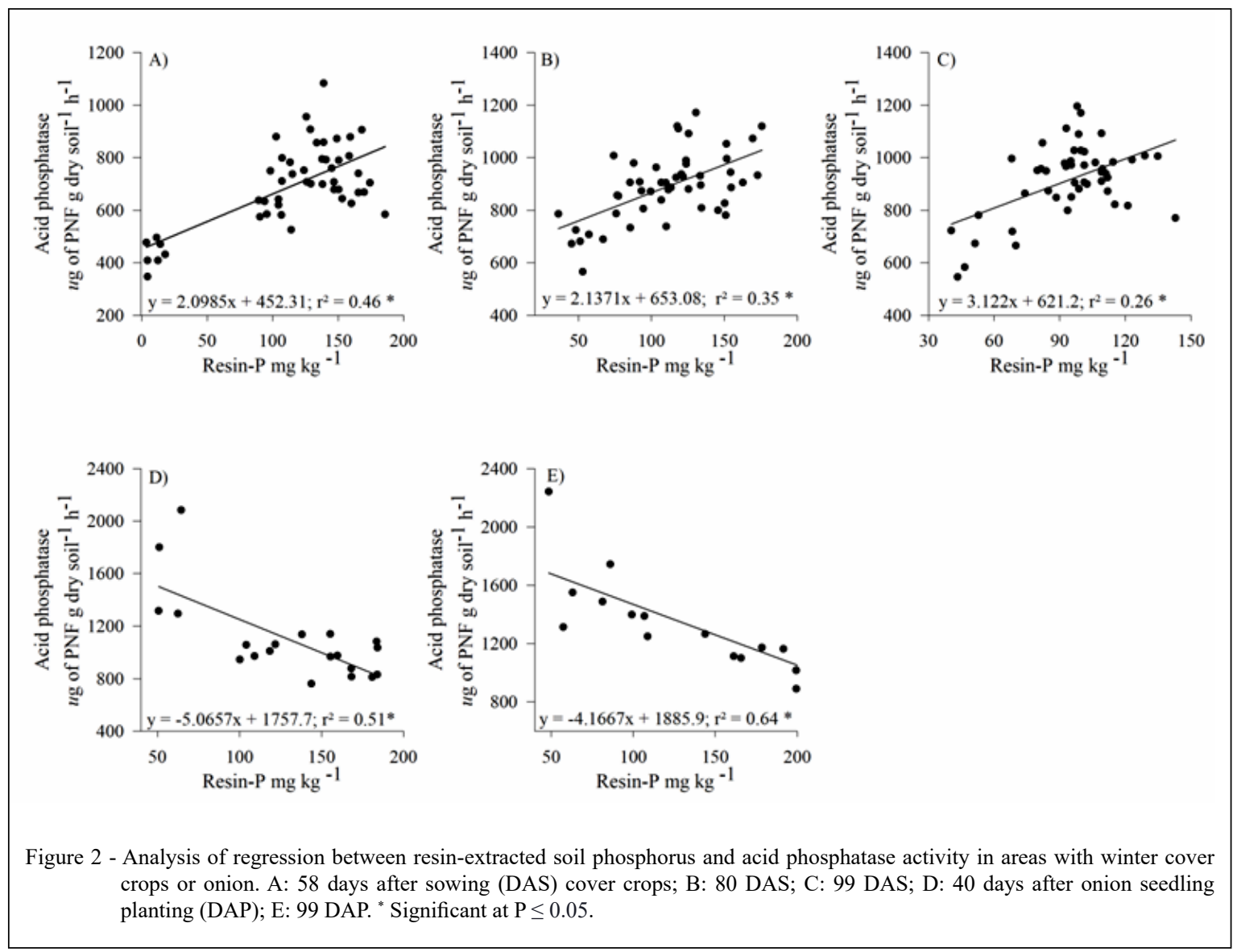

years, the total yield of onion bulbs was $20 \mathrm{Mg} \mathrm{ha}^{-1}$, values closer to the yield commonly found with the use of conventional management in the region, which is $25 \mathrm{Mg} \mathrm{ha}^{-1}$ (SOUZA, 2013; EPAGRI, 2019).

The high onion yield in treatments with single oilseed radish or black oats + oilseed radish can be due to the high efficiency of oats in nutrient cycling, especially for potassium (SANTOS et al., 2012). In the same experimental area, OLIVEIRA et al. (2016) found high amounts of potassium in residues of black oats and intercropped black oats and oilseed radish. Potassium is especially important for the development of onion plants, as it is uptaken from the soil and exported in higher amounts than any other nutrient (DESHPANDE et al., 2013; KHOKHAR, 2019.).

The importance of winter cover crops is supported by the robust regression coefficient between winter plant cover biomass and onion yield $\left(r^{2}=0.83\right)$. The mean yield of $4.5 \mathrm{Mg} \mathrm{ha}^{-1}$ of cover crop biomass contributed to nutrient cycling and kept the soil protected by decreasing soil and nutrient losses.
A similar work found that Brachiaria, an aggressive weed, had an $80 \%$ reduction in biomass when the area was previously grown with oats yielding 2.6 $\mathrm{Mg} \mathrm{ha}^{-1}$, which also improved soil quality (THEISEN \& VIDAL, 1999). WHITE \& WEIL, (2011) evaluated cover crop biomass production and nutrient cycling, and found positive effects on maize yield, mainly due to the phosphorus cycling from high oilseed radish (4.2 $\left.\mathrm{Mg} \mathrm{ha}^{-1}\right)$ and rye $\left(7.3 \mathrm{Mg} \mathrm{ha}^{-1}\right)$ biomass production.

Mycorrhizal colonization, and shoot phosphorus concentration and uptake

Root mycorrhizal colonization in rye $(20 \%$ in single cultivation and $12 \%$ in consortium with oilseed radish) is low, as compared with values from previous studies (SATTELMACHER et al., 1991). This is possibly due to the high soil phosphorus content (BRAUNBERGER et al., 1991; NAHAR et al., 2020), indicated by high phosphorus concentration in plants from all treatments. Rye roots in the rye + oilseed radish treatment had reduced colonization, which may be linked to the simultaneous presence of 


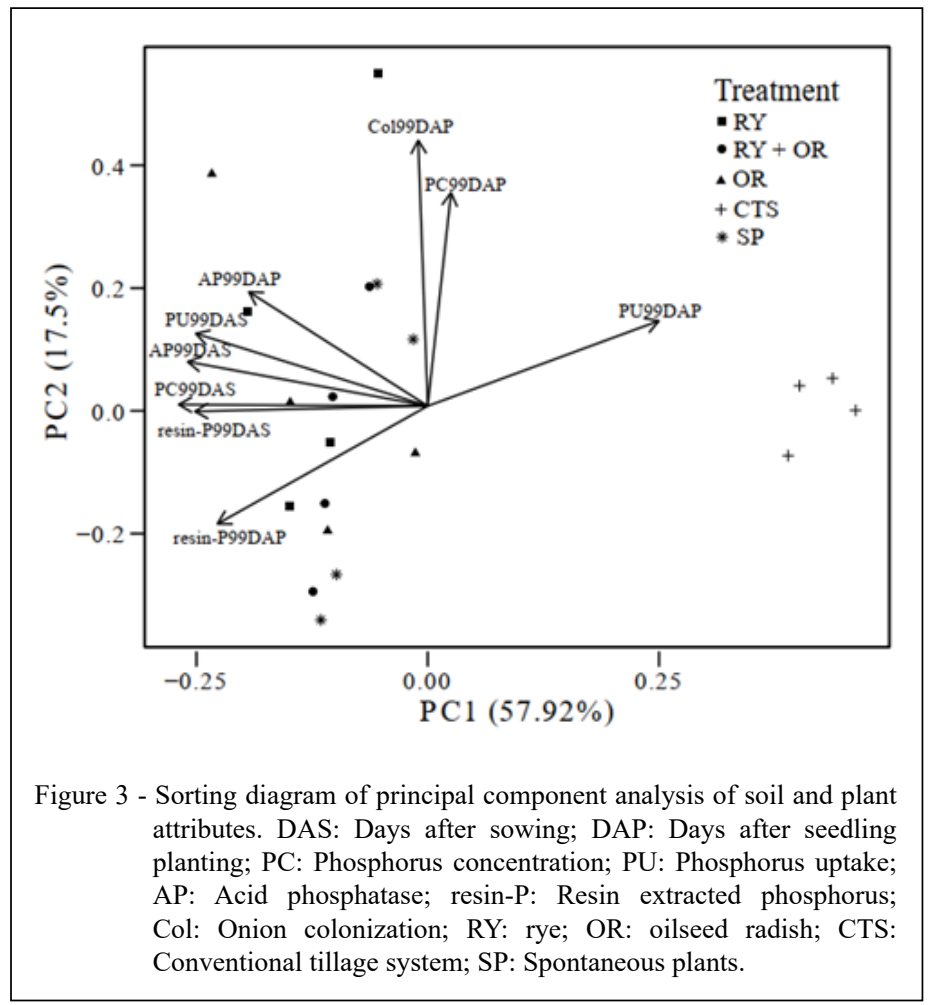

the non-mycorrhizal oilseed radish. Low arbuscular mycorrhizal root colonization also occurred in onion plants subsequently grown in the same areas. Reduced root colonization may be due to a decrease in the number of arbuscular mycorrhizal fungi propagules in the absence of arbuscular mycorrhizal association during cover crop growth (GALVEZ et al., 1995; DESSAI \& RODRIGUES, 2012).

At 40 days after seedling planting, the percentages of onion root total colonization in the rye, spontaneous plants, and conventional tillage system plots were considerably high (ROZPADEK et al., 2016). In the oilseed radish and rye + oilseed radish treatments, the previous presence of the nonmycorrhizal plant species seems to have affected negatively the establishment of the mycorrhizal symbiosis in onion. That indicates that precultivation with those plant species may lower the density of propagules needed to ensure adequate root colonization in the early stages of plant development. The higher percentage of vesicles in the spontaneus plants plots than in the other treatments may be due to stress conditions. Vesicles are formed by the fungus when it becomes nutritionally limited, as lipid accumulation in vesicles indicates that they are storage structures (PETERSON, 2004).
Cover plants in single rye and spontaneous plants in plots had higher phosphorus concentration in their tissues than those with oilseed radish or rye + oilseed radish. However, phosphorus uptake in plants from areas with cover crops was similar to, or higher than, those found in plants from the fallow areas with spontaneous plant. Inorganic phosphorus uptake by plants is enhanced by phosphatase-catalyzed mineralization of organic phosphorus (ADETUNJI et al., 2017). Besides, rye association with arbuscular mycorrhizal fungi may have contributed to the increases in phosphorus uptake. Those results highlight the importance of cover crops in nutrient cycling, affecting subsequent crops, such as onions.

\section{Acid phosphatase activity and resin-extracted phosphorus}

Acid phosphatase activity in treatments with cover crops was similar to results from previous studies (CONTE et al., 2002; DALLA COSTA \& LOVATO, 2004; CASTRO LOPES et al., 2018). That demonstrates the role of acid phosphatase activity for the availability of organic phosphorus, and it also indicates that plants have different strategies to obtain that nutrient. The low acid phosphatase activity in the conventional tillage system may have been 


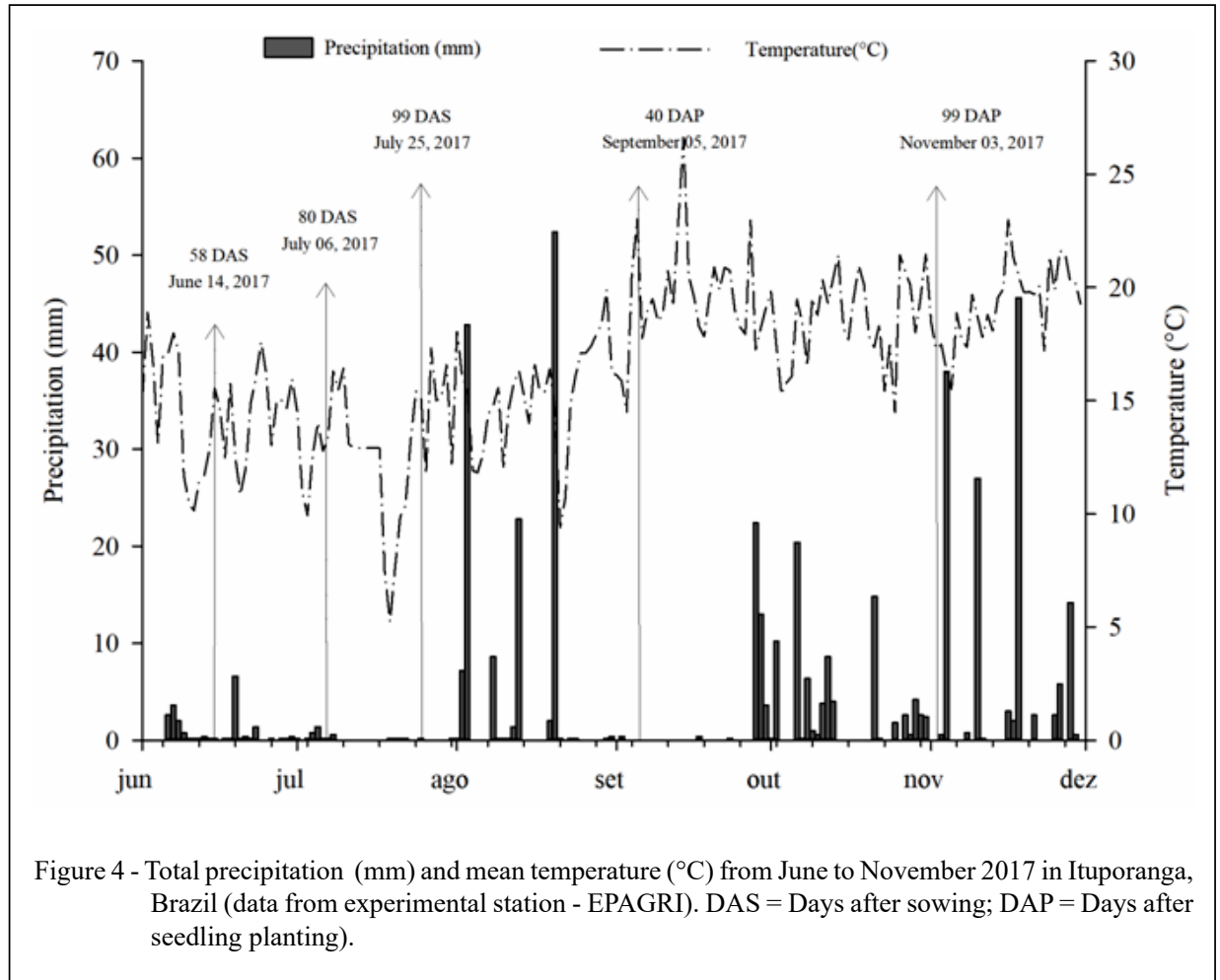

caused by recurrent soil tillage, which accelerates decomposition of plant residues, resulting in lower levels of organic matter (SANTOS et al., 2018) and reduced sources of organic phosphorus (DICK, 1984). Higher acid phosphatase activity in no-tillage systems than in conventional tillage areas has been demonstrated in previous papers, like the one by LISBOA et al. (2012).

Acid phosphatase activity in the conventional tillage system was low, in comparison with the conservationist systems, as found in other studies (CONTE et al., 2002; BARBIERI et al., 2019). Although the conventional tillage system Mehlich-extracted soil phosphorus (17.1 $\mathrm{mg} \mathrm{dm}^{-}$ ${ }^{3}$ ) is considered high according to the regional classification (CQFS RS / SC 2016), acid phosphatase activity may have been affected by the use of millet, which yields abundant biomass and a high $\mathrm{C} / \mathrm{N}$ ratio, above 30 (CALVO et al., 2010). High C/N ratios delay microbial decomposition and increase the permanence of plant residues on the soil surface even after tillage. Those conditions elicit activity of microorganisms seeking phosphorus from organic sources (CARDOSO et al., 2013), such as the millet residues remaining in the conventional tillage system.

The high levels of acid phosphatase activity in the forest (Table 3), associated with low soil phosphorus concentration (Table 6), show that mineralization of organic phosphorus is an essential process for the availability of this element in natural areas. CONTE et al. (2002) measured phosphatase activity in a forest area adjacent to a no-till experiment and found that acid phosphatase activity in the soil under native forest was 2.5 times higher than in notillage plots. In natural systems, such as native forests and prairies, phosphorus supply to plants depends heavily on organic phosphorus cycling, especially in soils of tropical and subtropical regions (STEWART \& TIESSEN, 1987).

We found a consistent pattern of higher acid phosphatase activity in the forest than in managed areas. The conventional tillage system area had the lowest enzymatic activity, while vegetable no-tillage system treatments had an intermediate activity, suggesting that acid phosphatase activity is a good indicator of soil quality (MAKOI \& NDAKIDEMI, 2008; MANKOLO et al., 2012; ADETUNJI et al., 2017). That is even more relevant for management systems that use cover crops and have high shoot and root biomass accumulation during the year, in comparison to systems that keep the soil exposed in some periods (DODOR \& TABATABAI, 2003). 
Resin-extracted phosphorus was higher in the vegetable no-tillage system plots than in the conventional tillage system and the forest. Those high values are, in part, due to the fertilization used with Gafsa rock phosphate and poultry litter, and those levels are maintained over the years due to the use of cover crops that recycle the nutrient. The increase in resin-extracted phosphorus after the rolling of cover crop and spontaneous plant highlights the importance of soil-covering plants to phosphorus cycling. ALMEIDA et al. (2018) reported that cover crops increased resin-extractable phosphorus by up to $10 \%$ in a no-tillage system with soybeans and Urochloa ruziziensis. Such benefits did not happen in the conventional tillage system area, where this nutrient had to be supplied by chemical fertilizers. Phosphorus extraction with resin seeks to reproduce the process of plant uptake of the most labile phosphorus fractions in the soil. Our results suggest that it is a suitable method for systems increasing the addition of organic matter to the soil, as is the case of no-tillage associated with the use of cover crops. The positive correlation between acid phosphatase activity and resinextracted phosphorus suggests that a significant part of the soil available phosphorus comes from enzyme action during the cover crop cycle. CUI et al. (2015) also found a positive correlation between enzyme activity and phosphorus availability in orchards with cover plants.

On the other hand, during the onion cycle, higher phosphorus levels appeared to inhibit phosphatase activity. Higher availability of soluble phosphorus in soil lowers acid phosphatase activity in soil with decreased phosphorus levels over successive years of cultivation (FUJITA et al., 2017; REDEL et al., 2019). The ability of plants to acquire inorganic phosphorus appears to be regulated by transcription of high-affinity phosphate transporters, many of them strongly induced during phosphate deficiency (RAGHOTHAMA \& KARTHIKEYAN, 2005). Besides, altered root morphology, due to mycorrhizal symbiosis, increases the ability of plants to acquire inorganic phosphorus (MAI et al., 2019). Phosphorus supply to roots and uptake by the plant are complex processes that need to be approached with different techniques. Soil analysis procedures, such as extraction with resin, associated with measurements of soil biological activity, like enzyme activity, may offer valuable information on phosphorus dynamics in soil and plant.

The results of the principal component analysis show the effect of cover crops on soil chemical and biological quality. The inclusion of cover crops in different production systems favors nutrient cycling, as demonstrated for phosphorus in our study. In addition, the presence of different plants in the fallow, even yielding less plant biomass, reflected the ability of those spontaneous species to cycle nutrients, similarly to the sown cover crops, as previously demonstrated by OLIVEIRA et al. (2016) in the same area. Our results also reaffirmed the negative effect of conventional tillage system on the evaluated attributes, mainly acid phosphatase and available phosphorus, as indicated by resinextracted forms.

The differences between the management systems demonstrate that crop systems minimizing soil tillage and maximizing plant biomass input increase the overall quality of the environment while avoiding heavy application of highly soluble fertilizers. Although there were lower yields in the no-tillage system than in the conventional tillage system, there were yield increases in comparison with the fallow area, due to reduced tillage and increased biomass addition by cover crops. In the long term, conservation management procedures improve biological and chemical attributes through enhanced nutrient cycling, thereby ensuring production sustainability, while requiring less external inputs to maintain soil and environmental quality.

\section{CONCLUSION}

Available soil phosphorus and acid phosphatase activity are higher in no-tillage areas than in conventional tillage areas, and plants in notillage areas, with winter cover crops or spontaneous plants, accumulate more phosphorus than plants from areas with tillage. In contrast, the conventional tillage system negatively affects acid phosphatase and resin-extracted phosphorus, as shown by Principal Component Analysis.

Areas with cover crops have higher biomass production and increased onion yield and phosphorus uptake compared with fallow areas with spontaneous plants, and the presence of oilseed radish, a non-mycorrhizal plant, is associated with decreases in the colonization of rye and onion roots by arbuscular mycorrhizal fungi.

\section{DECLARATION OF CONFLICT OF INTEREST}

The authors declare that they have no known competing financial interests or personal relationships that could have appeared to influence the work reported in this paper. 


\section{ACKNOWLEDGEMENTS}

The authors express their thanks to the staff and researcher at the Ituporanga Experimental Station (EPAGRI) for the experimental area and support in research activities. This work was partially funded by Coordenação de Aperfeiçoamento de Pessoal de Nível Superior - Brasil (CAPES, Finance Code 001). PEL and JJC have Conselho Nacional de Desenvolvimento Científico e Tecnológico (CNPq) Research Fellowship Grants (Pq).

\section{AUTHORS' CONTRIBUTIONS}

The authors also contributed to the manuscript.

\section{REFERENCES}

ADETUNJI, A. T. et al. The biological activities of $\beta$-glucosidase, phosphatase and urease as soil quality indicators: a review. Journal of soil science and plant nutrition, v.17, n.3, p.794 807, 2017. Available from: <https://scielo.conicyt.cl/scielo. php?script $=$ sci_arttext\&pid=S0718-95162017000300018\&lng= en\&nrm=iso\&tlng=en>. Accessed: Dec. 05, 2017. doi: 10.4067/ S0718-95162017000300018.

ALMEIDA, D. S. et al. Soil phosphorus bioavailability and soybean grain yield impaired by ruzigrass. Agronomy Journal, v.110, n.2, p.654-663, 2018. Available from: <https://acsess.onlinelibrary. wiley.com/doi/full/10.2134/agronj2017.08.0451>. Accessed: Mar. 24, 2021. doi: 10.2134/agronj2017.08.0451.

BARBIERI, M. et al. Trial on soil bioactivity under no-tillage in succession or rotation of winter and summer crops. Revista de Ciências Agrárias, v.42, n.1, p.122-134, 2019. Available from: $<$ https://revistas.rcaap.pt/index.php/rca/article/view/17025>. Accessed: Aug. 12, 2019. doi: 10.19084/RCA17068.

BOWLES, T. M. et al. Soil enzyme activities, microbial communities, and carbon and nitrogen availability in organic agroecosystems across an intensively-managed agricultural landscape. Soil Biology and Biochemistry, v.68, p.252-262, 2014. Available from: <https://www.sciencedirect.com/science/ article/abs/pii/S0038071713003398>. Accessed: Mar. 10, 2020. doi: 10.1016/j.soilbio.2013.10.004

BRAUNBERGER, P. G., et al., L. Effect of phosphorus nutrition on morphological characteristics of vesicular-arbuscular mycorrhizal colonization of maize. New Phytologist, v.119, n.1, p.107-113, 1991. Available from: < https://www.researchgate.net/ publication/230028783 > . Accessed: Mar. 24, 2021. doi: 10.1111/ j.1469-8137.1991.tb01013.x

BRUNDRETT, M. C., 2017. Global diversity and importance of mycorrhizal and nonmycorrhizal plants, in: Tedersoo, L. (Ed.), Biogeography of Mycorrhizal Symbiosis. Springer International Publishing, Cham, p.533-556. Available from: <https://link. springer.com/chapter/10.1007\%2F978-3-319-56363-3_21>. Accessed: Mar. 24, 2021. doi: 10.1007/978-3-319-56363-3 21 .

CARDOSO, E. J. B. N. et al. Soil health: looking for suitable indicators. What should be considered to assess the effects of use and management on soil health? Scientia Agricola, v.70, n.4, p.274-289, 2013. Available from: <https://www.scielo.br/pdf/sa/ v70n4/a09v70n4.pdf $>$. Accessed: Mar. 01, 2020. doi: 10.1590/ S0103-90162013000400009.
CARNEIRO, M. A. C. et al. Diversity of arbuscular mycorrhizal fungi and nematodes in a 14 years no-tillage chronosequence. Rhizosphere, v.10, p.100149, 2019. Available from: <https://www. sciencedirect.com/science/article/abs/pii/S245221981830137>. Accessed: Feb. 29, 2020. doi: 10.1016/j.rhisph.2019.100149.

CASTRO LOPES, A. A. et al. Temporal variation and critical limits of microbial indicators in oxisols in the Cerrado, Brazil. Geoderma Regional, v.12, p.72-82, 2018. Available from: <https://www.sciencedirect.com/science/article/abs/pii/ S235200941730130X?via\%3Dihub>. Accessed: Feb. 29, 2020 doi: 10.1016/j.geodrs.2018.01.003.

COMIN, J. J. et al. Carbon and nitrogen contents and aggregation index of soil cultivated with onion for seven years using crop successions and rotations. Soil and Tillage Research, v.184, p.195-202, 2018a. Available from: <https://www.sciencedirect. com/science/article/pii/S0167198718305312?via\%3Dihub>. Accessed: Aug. 18, 2019. doi: 10.1016/j.still.2018.08.002.

COMIN, J. J. et al. Avaliação fitossociológica de plantas invasoras em cultivo de cebola sob sistema plantio direto sem uso de agrotóxicos. Revista de la Facultad de Agronomía, v.117, n.2, p.197-206, 2018b. Available from: <https://revistas.unlp.edu.ar/ revagro/article/view/7335>. Accessed: Aug. 18, 2019.

COMISSÃO DE QUÍMICA E FERTILIDADE DO SOLO CQFS-RS/SC. Manual de adubação e de calagem para os Estados de Rio Grande do sul e de Santa Catarina. 10.ed. Porto Alegre, Brasil. 2004. 400p.

CONTE, E. et al. Phosphorus in the microbial biomass and acid phosphatase activity by phosphate application in soil under notillage system. Revista Brasileira de Ciência do Solo, v.26, n.4, p.925-930, 2002. Available from: $<$ https://www.scielo.br/pdf/rbcs/ v26n4/09.pdf $>$. Accessed: Aug. 12, 2019. doi: 10.1590/S010006832002000400009

DALlA COSTA, M.; LOVATO, P. E. Phosphatase activity in soil under mycorrhizal and non-mycorrhizal cover crops. Pesquisa Agropecuária Brasileira, v.39, n.6, p.603-605, 2004. Available from: <https://www.scielo.br/pdf/pab/v39n6/ v39n6a13.pdf>. Accessed: Aug. 12, 2019. doi: 10.1590/S0100204X2004000600013.

DE PONTES, J. S. et al. Diversity of arbuscular mycorrhizal fungi in the Brazilian's Cerrado and in soybean under conservation and conventional tillage. Applied Soil Ecology, v.117-118, p.178-189, 2017. Available from: <https://www.sciencedirect.com/science/ article/abs/pii/S0929139317301506>. Accessed: Mar. 10, 2020. doi: 10.1016/j.apsoil.2017.04.023.

DESHPANDE, A. N. et al. Potassium nutrition for improving yield and quality of onion. 2013. Available from: $<$ https://www. ipipotash.org/publications/eifc-312>. Accessed: Feb. 27, 2020.

DESSAI, S. A; RODRIGUES, B. F. Diversity studies on arbuscular mycorrhizal fungi in vegetable crop plants of Goa, India. Plant Pathology \& Quarantine, v.2, n.2, p.87-101, 2012. Available from: <https://plantpathologyquarantine.org/pdf/PPQ_2_2_1. pdf $>$. Accessed: Dec. 02, 2019. doi: 10.5943/ppq/2/2/1.

DICK, W. A. Influence of long-term tillage and crop rotation combinations on soil enzyme activities. Soil Science Society of America Journal, v.48, n.3, p.569-574, 1984. Available from: $\quad<$ https://www.researchgate.net/publication/250126048>. 
Accessed: Dec. 08, 2017. doi: 10.2136/sssaj1984.036159950048 00030020x.

DODOR, D. E.; TABATABAI, M. A. Effect of cropping systems on phosphatases in soils. Journal of Plant Nutrition and Soil Science, v.166, n.1, p.7-13, 2003. Available from: <https:// onlinelibrary.wiley.com/doi/epdf/10.1002/jpln.200390016>. Accessed: Jul. 24, 2019. doi: 10.1002/jpln.200390016.

EMBRAPA - EMPRESA BRASILEIRA DE PESQUISA AGROPECUÁRIA. SISTEMA BRASILEIRO DE CLASSIFICAÇÃO DE SOLOS. 2013. 3.ed. Rio de Janeiro: Embrapa Solos, 247p.

EPAGRI/Cepa, Empresa de Pesquisa Agropecuária e Extensão Rural de Santa Catarina S.A. Boletim Agropecuário. 2019. Florianópolis, 48p. (Epagri. Documentos, 295).

FAYAD, J. A. et al. Sistema de Plantio Direto de Hortaliças: método de transição para um novo modo de produção. 1. ed. São Paulo: Expressão Popular, v.1, 2019, 426p.

FERREIRA, L. B. et al. Organic carbon and nitrogen contents and their fractions in soils with onion crops in different management systems. Soil Research, v.56, n.8, p.846, 2018. Available from: $<$ https://www.publish.csiro.au/sr/SR18167>. Accessed: Mar. 24 2021. doi: 10.1071/SR18167.

FUJITA, K. et al. Microbial resource allocation for phosphatase synthesis reflects the availability of inorganic phosphorus across various soils. Biogeochemistry, v.136, n.3, p.325-339, 2017. Available from: $<$ https://link.springer.com/article/10.1007\%2 Fs10533-017-0398-6>. Accessed: Mar. 24, 2021. doi: 10.1007/ s10533-017-0398-6.

GALVEZ, L. et al. An overwintering cover crop increases inoculum of VAM fungi in agricultural soil. American Journal of Alternative Agriculture, v.10, n.4, p.152-156, 1995. Available from: <https://doi.org/10.1017/S0889189300006391>. Accessed: Mar. 24, 2021. doi: 10.1017/S0889189300006391.

HERTWIG BITTENCOURT, H. VON et al. Effect of winter cover crop biomass on summer weed emergence and biomass production. Journal of Plant Protection Research, v.53, n.3, p.248-252, 2013. Available from: <https://journals.pan.pl/dlibra/ publication/103172/edition/89184/content>. Accessed: Mar. 24, 2021. doi: $10.2478 /$ jppr-2013-0037.

HORTIBRASIL. Norma De Classificação Da Cebola Para o Programa Brasileiro Para a Melhoria Dos Padrões Comerciais e Embalagens De Hortigranjeiros. 2010. Online, Available from: $<$ http://www.hortibrasil.org.br/classificacao/cebola/arquivos/ norma.html>. Accessed: Feb. 20, 2017.

KHOKHAR, K. M. Mineral nutrient management for onion bulb crops - a review. The Journal of Horticultural Science and Biotechnology, v.94, n.6, p.703-717, 2019. Available from: <https://www.tandfonline.com/doi/full/10.10 80/14620316.2019.1613935>. Accessed: Feb. 29, 2020. doi: $10.1080 / 14620316.2019 .1613935$.

KOSKE, R. E.; GEMMA, J. N. A modified procedure for staining roots to detect VA mycorrhizas. Mycological Research, v.92, n.4 p.486-488, 1989. Available from: <https://www.sciencedirect. com/science/article/pii/S0953756289801959>. Accessed: Aug. 07, 2017. doi: 10.1016/S0953-7562(89)80195-9.
KUNZE, A. et al. Phosphatase activity in sandy soil influenced by mycorrhizal and non-mycorrhizal cover crops. Revista Brasileira de Ciência do Solo, v.35, n.3, p.705-711, 2011. Available from: $<$ https://www.scielo.br/pdf/rbcs/v35n3/v35n3a05.pdf $>$. Accessed: Aug. 07, 2017. doi: 10.1590/S0100-06832011000300005.

LISBOA, B. B. et al. Microbial indicators of soil quality in different management systems Revista Brasileira de Ciência do Solo, v.36, n.1, p.33-44, 2012. Available from: <https://www. scielo.br/pdf/rbcs/v36n1/v36n1a04.pdf $>$. Accessed: Feb. 15, 2020. doi: 10.1590/S0100-06832012000100004.

LOSS, ARCÂNGELO et al. Soil physical attributes of onion cultivation under no-tillage and conventional tillage systems. Revista Colombiana de Ciências Hortícolas, v.11, n.1, p.105-113, 2017. Available from: <http://dx.doi.org/10.17584/ rcch.2017v11i1.6144>. Accessed: Mar. 24, 2021. doi: 10.17584/ rcch.2017v11i1.6144.

MAI, W. et al. Arbuscular mycorrhizal fungi - 15-Fold enlargement of the soil volume of cotton roots for phosphorus uptake in intensive planting conditions. European Journal of Soil Biology, v.90, p.31-35, 2019. Available from: <https://www.sciencedirect. com/science/article/pii/S1164556318303182>. Accessed: Dec. 02, 2019. doi: 10.1016/j.ejsobi.2018.12.002.

MAKOI, J., NDAKIDEMI, P.A. Selected soil enzymes: Examples of their potential roles in the ecosystem. African Journal of Biotechnology, v.7, n.3, 2008. Available from: $<$ https://www.ajol.info/index.php/ajb/article/view/58355>. Accessed: Jul. 24, 2019

MANKOLO, R. et al. Soil Biochemical Changes Induced by Poultry Litter Application and Conservation Tillage under Cotton Production Systems. Agronomy, v.2, n.3, p.187-198, 252012. Available from: <https:/www.mdpi.com/2073-4395/2/3/187>. Accessed: Aug. 12, 2019. doi: 10.3390/agronomy2030187.

MCGONIGLE, T. P. et al. A new method which gives an objective measure of colonization of roots by vesicular-arbuscular mycorrhizal fungi. New Phytologist, v.115, n.3, p.495-501, 1990. Available from: <https://doi.org/10.1111/j.1469-8137.1990. tb00476.x>. Accessed: Feb. 21, 2020. doi: 10.1111/j.14698137.1990.tb00476.x.

MENDES, I. DE C. et al. Critical limits for microbial indicators in tropical Oxisols at post-harvest: The FERTBIO soil sample concept. Applied Soil Ecology, v.139, p.85-93, 2019. Available from: $\quad<$ https://www.sciencedirect.com/science/article/pii/ S0929139318312253>. Accessed: Mar. 10, 2020. doi: 10.1016/j. apsoil.2019.02.025

MONEGAT, C. Plantas de cobertura do solo: características e manejo em pequenas propriedades. Chapecó, Santa Catarina, Editora do Autor, 1991. 336p.

MÜLLER JÚNIOR, V. et al. Nitrous oxide emissions in notillage onion (Allium cepa 1.) crops are increased by oilseed radish cover crop and poultry manure application. Revista Brasileira de Ciência do Solo, v.43, p.e0180116, 2019. Available from: <https://www.scielo.br/pdf/rbcs/v43/18069657-rbcs-43-e0180116.pdf $>$. Accessed: Mar. 24, 2021. doi: $10.1590 / 18069657 \mathrm{rbcs} 20180116$.

MURPHY, J.; RILEY, J. P. A modified single solution method for the determination of phosphate in natural waters. Analytica 
Chimica Acta, v.27, p.31-36, 1962. Available from: <https://doi. org/10.1016/S0003-2670(00)88444-5>. Accessed: Aug. 07, 2017. doi: $10.1016 / \mathrm{S} 0003-2670(00) 88444-5$.

NAHAR, K.; et al. Mycorrhizal colonization in bread wheat varieties differing in their response to phosphorus. Journal of Plant Nutrition, p.1-17, 2020. Avalable from: $<$ https://doi.org/1 0.1080/01904167.2020.1793190>. Accessed: Mar. 24, 2021. doi: 10.1080/01904167.2020.1793190.

OKSANEN, J. et al. Vegan: Community Ecology Package. 2013. [s.l: s.n.]. Available from: <http://CRAN.R-project.org/ package $=$ vegan $>$. Accessed: Jul. 30, 2020.

OLIVEIRA, R. A. DE et al. Cover crops effects on soil chemical properties and onion yield. Revista Brasileira de Ciência do Solo, v.40, n.0, 2016. Available from: <https://www.scielo.br/pdf/rbcs/ v40/0100-0683-rbcs-18069657rbcs20150099.pdf >. Accessed: Mar. 10, 2020. doi: 10.1590/18069657rbcs20150099.

OLIVEIRA, R. A. DE et al. Release of phosphorus forms from cover crop residues in agroecological no-till onion production. Revista Brasileira de Ciência do Solo, v.41, n.0, 2017. Available from: $\quad<$ https://www.scielo.br/pdf/rbcs/v41/0100-0683-rbcs18069657rbcs20160272.pdf $>$. Accessed: Mar. 10, 2020. doi: $10.1590 / 18069657 \mathrm{rbcs} 20160272$.

PANACHUKI, E. et al. Soil and water loss and water infiltration in red latosol under different management systems. Revista Brasileira de Ciência do Solo, v.35, n.5, p.1777-1786, 2011. Available from: <https://www.scielo.br/pdf/rbcs/v35n5/ a32v35n5.pdf>. Accessed: Aug. 07, 2017. doi: 10.1590/S010006832011000500032.

PETERSON, R. L et al. Mycorrhizas: anatomy and cell biology. NRC Research Press ; CABI Pub, Ottawa: Wallingford, Oxon, UK, 2004. 196p.

PISSINATI, A.; et al. Biomass Yield and Nutrients Concentration in Shoot Dry Weight of Winter Cover Crops for No-Tillage System. Communications in Soil Science and Plant Analysis, v.47, n.20, p.2292-2305, 2016. Available from: <https://www.tandfonline. com/doi/full/10.1080/00103624.2016.1243711>. Accessed: Mar. 24, 2021. doi: 10.1080/00103624.2016.1243711.

QIU, L. et al. Arbuscular mycorrhizal fungi ameliorate the chemical properties and enzyme activities of rhizosphere soil in reclaimed mining subsidence in northwestern China. Journal of Arid Land, v.11, n.1, p.135-147, 2019. Available from: <https:// link.springer.com/article/10.1007/s40333-018-0019-9>. Accessed: Mar. 24, 2021. doi: 10.1007/s40333-018-0019-9.

R Development Core Team. R: The R Project for Statistical Computing. Available from: <https://www.r-project.org/>. Accessed: Jul. 30, 2020.

RAGHOTHAMA, K. G.; KARTHIKEYAN, A. S. Phosphate acquisition. In: LAMBERS, H.; COLMER, T. D. (Eds.). Root Physiology: from Gene to Function. Dordrecht: Springer Netherlands, v.4, p.37-49, 2005. Available from: <https://doi. org/10.1007/1-4020-4099-7 2>. Accessed: Aug. 12, 2019. doi: 10.1007/1-4020-4099-7_2.

REDEL, Y. et al. Fertilizer $\mathrm{P}$ uptake determined by soil $\mathrm{P}$ fractionation and phosphatase activity. Journal of Soil Science and Plant Nutrition, v.19, n.1, p.166-174, 2019. Available from: <https://doi.org/10.1007/s42729-019-00024-z>. Accessed: Mar. 24, 2021. doi: 10.1007/s42729-019-00024-z.

RILLIG, M. C.; MUMMEY, D. L. Mycorrhizas and soil structure. New Phytologist, v.171, n.1, p.41-53, 2006. Available from: $\quad<$ https://nph.onlinelibrary.wiley.com/doi/full/10.1111 /j.1469-8137.2006.01750.x>. Accessed: Aug. 07, 2017. doi: 10.1111/j.1469-8137.2006.01750.x.

ROZPADEK, P. et al. Arbuscular mycorrhiza improves yield and nutritional properties of onion (Allium cepa). Plant Physiology and Biochemistry, v.107, p.264-272, 2016. Available from: <https://www.sciencedirect.com/science/article/ pii/S0981942816302273>. Accessed: Jun. 26, 2017. doi: 10.1016/j. plaphy.2016.06.006.

SANTOS, L. H. DOS et al. Chemical properties in macroaggregates of a humic dystrudept cultivated with onion under no-till and conventional tillage systems. Revista Brasileira de Ciência do Solo, v.41, n.0, 2017. Available from: <https://www.scielo.br/pdf/rbcs/v41/0100-0683-rbcs18069657rbcs20160419.pdf>. Accessed: Mar. 10, 2020. doi: $10.1590 / 18069657 \mathrm{rbcs} 20160419$.

SANTOS, L. H. et al. Carbon and nitrogen content in granulometric fractions of organic matter in soil aggregates under no-tillage and conventional tillage planting systems for onions. Idesia (Arica), v.36, n.4, p.7-15, 2018. Available from: <http://dx.doi. org/10.4067/S0718-34292018005002001>. Accessed: Mar. 10, 2020. doi: $10.4067 / \mathrm{S} 0718-34292018005002001$.

SANTOS, S. DA S. et al. Production of organically grown onions depending on the use of mulch and castor bean cake. Horticultura Brasileira, v.30, n.3, p.549-552, 2012. Available from: <https:// www.scielo.br/pdf/hb/v30n3/32.pdf>. Accessed: Mar. 10, 2020. doi: 10.1590/S0102-05362012000300032.

SATTELMACHER, B. et al. Differences in mycorrhizal colonization of rye (Secale cereale L.) grown in conventional or organic (Biological-dynamic) farming systems. Journal of Agronomy and Crop Science, v.167, n.5, p.350-355, 1991. Available from: $<$ https://doi.org/10.1111/j.1439-037X.1991. tb00967.x>. Accessed: Mar. 24, 2021. doi: 10.1111/j.1439037X.1991.tb00967.x.

SMITH, S. E. \& READ, D. J. 2008. Mycorrhizal symbiosis. $3^{\mathrm{a}}$ ed London: Academic Press. 815p.

SOUZA, M. et al. Dry matter of cover crops, onion yield and soil chemical attributes in agroecological no-tillage system. Ciência Rural, v.43, n.1, p.21-27, 2013. Available from: $<$ https://www.scielo.br/pdf/cr/v43n1/a2313cr2012-0165. pdf>. Accessed: Mar. 10, 2020. doi: 10.1590/S010384782012005000150 .

SOUZA, M. et al. Weed emergence in a soil with cover crops in an agroecological no-tillage system. Planta Daninha, v.36, n.0, 2018. Available from: <https://www.scielo.br/pdf/pd/v36/0100-8358PD-36-e018163608.pdf>. Accessed: Mar. 10, 2020. doi: 10.1590/ s0100-8358201836010065.

STEWART, J. W. B.; TIESSEN, H. Dynamics of soil organic phosphorus. Biogeochemistry, v.4, n.1, p.4160, 1987. Available from: <https://link.springer.com/ article/10.1007\%2FBF02187361>. Accessed: Feb. 21, 2020. doi: 10.1007/BF02187361. 
TABATABAI, M. A. Soil enzymes. In: WEAVER, R. W. et al. Methods of soil analysis. Part 2. Microbial and biochemical properties. Madison: Soil Science Society of America, 1994. p.775- 833. (Soil Science Society of America series, 5).

TARAFDAR, J. C. Visual demonstration of in vivo acid phosphatase activity of VA mycorrhizal fungi. Current Science, v.69, n.6, p.541-543, 1995. Available from: <https://www.jstor. org/stable/24096888?seq=1>. Accessed: Oct. 22, 2019.

TAWARAYA, K. et al. Solubilization of Insoluble Inorganic Phosphate by Hyphal Exudates of Arbuscular Mycorrhizal Fungi. Journal of Plant Nutrition, v.29, n.4, p.657-665, 2006. Avalable from: $<$ https:// www.tandfonline.com/doi/abs/10.1080/01904160600564428>. Accessed: Feb. 21, 2020. doi: 10.1080/01904160600564428.
TEDESCO, M. J. et al. Análises de solo, plantas e outros materiais. 2. ed. Porto Alegre, Departamento de Solos, UFRGS. 1995. 174p. (Boletim Técnico 5).

THEISEN, G.; VIDAL, R. A. Alexandergrass life-cycle is affected by black oat residues on the soil surface. Planta Daninha, v.17, n.2, p.189-196, 1999. Available from: <https:/www.scielo.br/pdf/ pd/v17n2/03.pdf $>$. Accessed: Mar. 24, 2021. doi: 10.1590/S010083581999000200003 .

WHITE, C. M.; WEIL, R. R. Forage radish cover crops increase soil test phosphorus surrounding radish taproot holes. Soil Science Society of America Journal, v.75, n.1, p.121-130, jan. 2011. Available from: <https://doi.org/10.2136/sssaj2010.0095>. Accessed: Nov. 30, 2019. doi: 10.2136/sssaj2010.0095. 